\title{
Effect of excess soil water on the development of Bermuda grass (Cynodon spp.)
}

\author{
Antônio A. do Nascimento Filho' ${ }^{1}$, Raimundo N. T. Costa ${ }^{2}$, Carlos H. C. de Sousa ${ }^{2}$, \\ Caroline de M. D. Mateus ${ }^{3} \&$ Kenya G. Nunes ${ }^{2}$
}

${ }^{1}$ Universidade Federal do Ceará/Departamento de Ciências do Solo, Fortaleza, CE, Brasil. E-mail: gpeasgp@gmail.com (Corresponding author) - ORCID: 0000-0002-3675-7406

${ }^{2}$ Universidade Federal do Ceará/Departamento de Engenharia Agrícola, Fortaleza, CE, Brasil. E-mail: rntcosta@ufc.br - ORCID: 0000-0001-6245-7768; sousaibiapina@yahoo.com.br - ORCID: 0000-0001-9462-4647; kenyagn@gmail.com - ORCID: 0000-0001-8996-1497

${ }^{3}$ Universidade Estadual Paulista/Faculdade de Ciências Agronômicas, Botucatu, SP, Brasil. E-mail: caroline_mateus@hotmail.com - ORCID: 0000-0003$2848-6340$

\begin{abstract}
Soil drainage is an important technique in the construction of a sports lawn and information about the sensitivity of the crop to excess water influences the design of the project. Assuming that excess

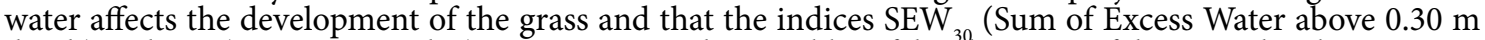
depth) and SDI (Stress-Day Index) are sensitive to the variables of development of the crop, the objective was to identify the sensitivity of Bermuda grass to the excess of water. The experimental design was completely randomized with five treatments and four repetitions. The treatments consisted of groundwater elevations: $0 \mathrm{~cm} \mathrm{~d}$ (at the level of the drains - control); $180 \mathrm{~cm} \mathrm{~d} \mathrm{(at} 0.20 \mathrm{~m}$ from the soil surface); $270 \mathrm{~cm} \mathrm{~d} \mathrm{(at} 0.15$ $\mathrm{m}$ from the soil surface); $360 \mathrm{~cm}$ d (at $0.10 \mathrm{~m}$ from the soil surface); and $450 \mathrm{~cm} \mathrm{~d} \mathrm{(at} 0.05 \mathrm{~m}$ from the soil surface), carried out fortnightly, lasting three days. The variables used to test the treatment were root length, photosynthesis rate, dry mass of roots, stolons, rhizomes, culms and leaves and dry mass of grass clippings. Stress caused by excess water near the soil surface reduced root length, dry mass of culms and leaves, and photosynthesis rate; Bermuda grass was more sensitive to excess water in its initial vegetative stage, which occurs until 42 days after planting; and the photosynthesis rate in the treatment with highest stress level decreased by approximately by $2 / 3$ when compared to the condition of no water table.
\end{abstract}

Key words: excess water drainage, lysimeter, water table

\section{Excesso de água no solo sobre o desenvolvimento da grama-bermuda (Cynodon spp.)}

RESUMO: A drenagem do solo é uma técnica fundamental na instalação de um gramado esportivo e informações sobre a sensibilidade da cultura ao excesso de água influenciam no dimensionamento do projeto. Partindo da premissa que o excesso de água prejudica o desenvolvimento da grama e que os

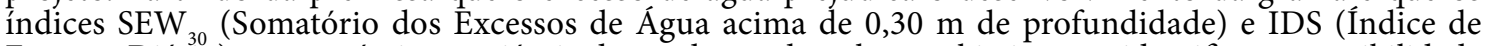
Estresse Diário) são sensíveis a variáveis de produção da cultura, objetivou-se identificar a sensibilidade da grama-bermuda ao excesso de água. O delineamento experimental foi inteiramente casualizado, com cinco tratamentos e quatro repetições. Os tratamentos consistiram em seis elevações do lençol freático, variando as profundidades entre $0,05 \mathrm{~m}$ e $0,20 \mathrm{~m}$, realizadas quinzenalmente, com duração de três dias, além do tratamento sem elevação do lençol freático: $0 \mathrm{~cm} \mathrm{~d}$ (no nível dos drenos - testemunha); $180 \mathrm{~cm} \mathrm{~d}$ (a 0,20 $\mathrm{m}$ da superfície do solo); $270 \mathrm{~cm}$ d (a $0,15 \mathrm{~m}$ da superfície do solo); $360 \mathrm{~cm} \mathrm{~d} \mathrm{(a} \mathrm{0,10} \mathrm{m} \mathrm{da} \mathrm{superfície}$ do solo); e $450 \mathrm{~cm}$ d (a 0,05 $\mathrm{m}$ da superfície do solo). As variáveis analisadas foram: comprimento de raiz, taxa de fotossíntese, massa da matéria seca de raízes, estolões, rizomas, colmos e folhas e massa seca das aparas de grama. $\mathrm{O}$ estresse causado pelo excesso de água próximo à superfície do solo proporcionou redução no comprimento de raiz, na matéria seca de colmos e folhas e na taxa fotossintética; a grama-bermuda mostrouse mais sensível ao excesso de água no estádio vegetativo inicial da cultura, que ocorre até os 42 dias após o plantio; a taxa fotossintética no tratamento com maior nível de estresse decresceu aproximadamente $2 / 3$ quando comparada à condição de ausência de lençol freático.

Palavras-chave: drenagem do excesso de água, lisímetro, lençol freático 


\section{INTRODUCTION}

Lawns are widely used in public, residential and sports areas around the world. Those used in major stadiums and clubs of football, golf and tennis, mainly due to the high professionalism involved in these sports, are in the technical revolution phase and need to ensure good tolerance to wear. In Brazil, there is growing interest in modern techniques for the maintenance of sports lawns, which increases the number of lawns with excellent quality (Maciel et al., 2011; Sampoux et al., 2012).

Currently, the growing demand and more specific requirements of the consumer market regarding the final quality of lawns are the main factors that drive the producing areas and the development and import of technology (Godoy et al., 2012; Kuhn, 2015). Among the recommendations for the establishment of a sports lawn, drainage is considered one of the most important practices.

One of the greatest limitations to agricultural drainage projects is the absence of coefficients representing the soil drainage requirements of the various crops under local conditions (Bouwer, 1974; Evangelista et al., 2005).

According to Costa et al. (2008), the Sum of Excess Water above $0.30 \mathrm{~m}$ on depth $\left(\mathrm{SEW}_{30}\right)$ and the Stress-Day Index (SDI) are variables used to relate the reduction in yield to the occurrence of water table fluctuation above a critical level.

Assuming that excess water hampers the development of the grass and that $\mathrm{SEW}_{30}$ and SDI indices are sensitive to crop production traits, the objective was to identify the sensitivity of 'Celebration' Bermuda grass (Cynodon dactylon) to excess water based on the production traits referenced in the $\mathrm{SEW}_{30}$ and SDI indices.

\section{Material ANd Methods}

The physical model used in the experiment was installed in an area of the Hydraulics and Irrigation Laboratory of the Department of Agricultural Engineering of the Federal University of Ceará (UFC), Fortaleza, CE, Brazil. Eight water table lysimeters with dimensions of $1.5 \mathrm{~m}$ height, $2.0 \mathrm{~m}$ width and $1.5 \mathrm{~m}$ length, coated with mortar and internally waterproofed, were constructed in the area. On the inside of each lysimeter, a corrugated and flexible tubular PVC drain (DN 65) was installed at $1.10 \mathrm{~m}$ depth in relation to the upper part of the lysimeter. Two water inlets were installed next to the bottom of the front wall, both connected to a valve, enabling individual filling of the lysimeters (Figure 1).

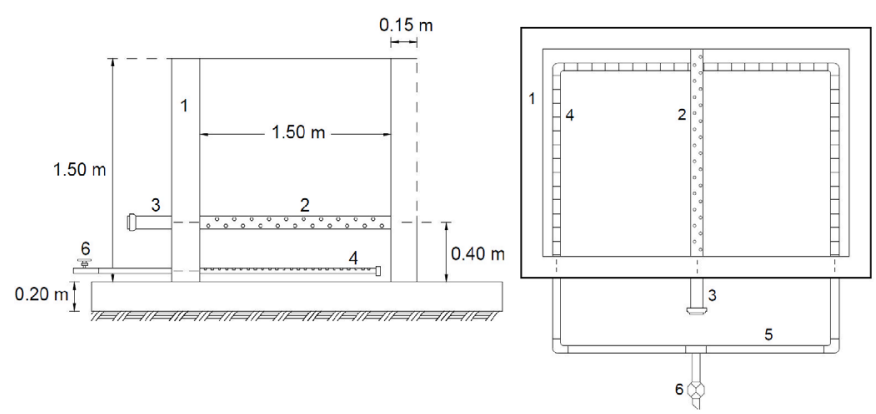

Figure 1. Floor plan (A) and cross-sectional view (B) of one of the tanks: 1. Tank wall; 2. Drainage pipe; 3. Pipe outlet cap; 4. PVC pipe with grooves; 5 . Water supply system; 6. Valve
The physical model enables upward-flow saturation of the soil, through a reservoir. A float valve system regulates the maximum height of water in the reservoir, controlling the inlet in the lysimeters up to a maximum level, $0.10 \mathrm{~m}$ from the upper edge.

A piezometer composed of a transparent plastic hose, attached to the water inlet close to the valve, was installed on the external front wall of each lysimeter, in order to verify and control the level of the water table.

The piezometer extends up to the height at which the water table should be kept, so the monitoring can be performed based on the principle of communicating vessels. An adapted hydrometer with a valve was installed at the discharge point of the drains, which enabled the water table level to be lowered whenever necessary.

The experimental design was completely randomized, with five treatments and four replicates. The treatments consisted of water table elevations, performed every fifteen days, lasting three days:

a. Treatment 1: $\mathrm{SEW}_{30}=0 \mathrm{~cm} \mathrm{d,} \mathrm{water} \mathrm{table} \mathrm{at} \mathrm{the} \mathrm{level}$ of the drains (control);

b. Treatment 2: $\mathrm{SEW}_{30}=180 \mathrm{~cm} \mathrm{~d}$ (water table at 0.20 $\mathrm{m}$ from soil surface);

c. Treatment 3: $\mathrm{SEW}_{30}=270 \mathrm{~cm} \mathrm{~d}$ (water table at 0.15 $m$ from soil surface);

d. Treatment 4: $\mathrm{SEW}_{30}=360 \mathrm{~cm} \mathrm{~d}$ (water table at 0.10 $\mathrm{m}$ from soil surface);

e. Treatment 5: $\mathrm{SEW}_{30}=450 \mathrm{~cm} \mathrm{~d}$ (water table at 0.05 $\mathrm{m}$ from soil surface).

The $\mathrm{SEW}_{30}$ index corresponds to the sum of water above the $0.30 \mathrm{~m}$ depth and was used to determine the effects of water table fluctuation on crops that have shallower root systems; calculated by Eq. 1 :

$$
\mathrm{SEW}_{30}=\int_{0}^{\mathrm{T}} \mathrm{f}(\mathrm{x}) \mathrm{dt}
$$

where:

$f(x)=30-x$, for $x<30 \mathrm{~cm} ; f(x)=0$, for $x>30 \mathrm{~cm}$;

$\mathrm{T}$ - length of the growing season;

t - time in days; and,

$\mathrm{x}$ - water table depth in $\mathrm{cm}$.

The SDI index enables the evaluation of stress caused by either lack or excess of water during the growth period of a crop and is usually used to characterize irrigation requirements, in areas with problems of water deficit or in soils with excess water, where drainage is required. The SDI of a given period is composed of the sum of the products between the crop susceptibility factor and the stress-day factor, according to Eq. 2:

$$
\mathrm{SDI}=\sum_{\mathrm{i}=1}^{\mathrm{n}}\left(\mathrm{CS}_{\mathrm{i}} \mathrm{SD}_{\mathrm{i}}\right)
$$

where:

SDI - stress-day index;

$\mathrm{n}$ - number of growth stages of the crop; 
CSi - crop susceptibility factor at development stage i; and,

SDi - stress-day factor at development stage i.

For being the measure of crop susceptibility to a stress unit, CS is a function of the crop and of its development stage. For being the measure of the degree of stress imposed on a crop, SD reflects stress intensity and duration. The soil excess water stress index $\mathrm{SEW}_{30}$ is typically used as a stress-day factor of the crop in studies involving the stress-day index (COSTA, 2008).

The substrate used in water table lysimeters was composed of a mixture of sand and organic matter. The organic matter used, with commercial name Turfa Fértil', is sold as a soil conditioner and manufactured in the State of Santa Catarina, Brazil.

Following the model recommended by the United States Golf Association (USGA, 2004), for the construction of golf course "greens", the sand for mixture was collected in the municipality of São Luís do Curu, CE, Brazil, $84 \mathrm{~km}$ away from the city of Fortaleza, and analyzed in the Soil Physics Laboratory of the Department of Soils and Plant Nutrition of UFC.

According to the USGA model, the sand must have at least $60 \%$ of particles with a size between 0.25 and $1.0 \mathrm{~mm}$, clay no more than $3 \%$, total porosity from 35 to $55 \%$ and hydraulic conductivity of at least $150 \mathrm{~mm} \mathrm{~h}^{-1}$

The characteristics of the sand used to compose the substrate of the drainage tanks are: sandy soil (sand: 94.67 ; silt: 4.13; clay: $1.2 \%$ ), with hydraulic conductivity of $450 \mathrm{~mm} \mathrm{~h}^{-1}$, total porosity of $45 \%$, soil density of $1480 \mathrm{~kg} \mathrm{~m}^{-3}$ and waterdispersible clay of $0.7 \%$; its particle size and classification are presented in Table 1.

In the root zone ( 0 to $0.30 \mathrm{~m}$ from the surface), the sand was mixed with organic matter, which according to the manufacturer is free of pathogens and seeds of invasive plants, in the proportion of $90 \%$ sand and $10 \%$ organic matter. Then, planting was performed using 'Celebration' Bermuda grass (Cynodon dactylon) in the form of stolons, which was chosen because it is the most indicated species for the formation of sports lawns, according to Silva et al. (2010). Lemes et al. (2015) and Godoy et al. (2016) also claim that the Bermuda grass is indicated for the formation of sports, recreational and ornamental lawns due to its soft leaves and resistance to trampling.

The seedlings were weighed and planted in the proportion of $1.0 \mathrm{~kg} \mathrm{~m}^{-2}$, with stolons scattered in the area and then lightly compacted and buried to increase contact with the soil. The seedlings were irrigated using a hose until the beginning of the rooting. Regarding the SEW index, every 15 days the water table was kept at one position, according to the different

Table 1. Particle size and classification of the sand used to compose the substrate of the drainage tanks

\begin{tabular}{|cccc}
\hline $\begin{array}{c}\text { Particle } \\
\text { size (mm) }\end{array}$ & $\begin{array}{c}\text { Individual } \\
\text { percentage } \\
\text { retained (\%) }\end{array}$ & $\begin{array}{c}\text { Cumulative } \\
\text { percentage } \\
\text { retained (\%) }\end{array}$ & Classification \\
\hline 2.0 & 0 & 0 & Gravel \\
1.0 & 3.05 & 3.05 & Very coarse sand \\
0.5 & 18.31 & 21.36 & Coarse sand \\
0.25 & 39.97 & 61.33 & Medium sand \\
0.125 & 31.19 & 92.52 & Fine sand \\
0.05 & 7.48 & 100.00 & Very fine sand \\
\hline
\end{tabular}

treatments, for three days, and then lowered to the drain level $(1.10 \mathrm{~m})$.

In the control treatment, the water table was always kept at the drain level. In three other lysimeters, the water table was kept at the soil surface level for four days at 30-day intervals in order to determine the coefficient of crop susceptibility to excess water at different development stages: 1st stage - from 12 to 42 days after planting (rooting phase of the seedlings, in which their root system is establishing); 2nd stage - from 43 to 73 days after planting (phase in which the root system of the crop has access to nutrients and water, with lengthening of roots and stolons, and the above-ground growth accelerates); 3rd stage - from 73 to 115 days after planting (phase in which the grass is already established and the soil is almost entirely covered by the crop; from this phase, under adequate conditions for the grass, the growth rate is constant).

Fertilization was performed with NPK formulation of 1509-20, every 15 days, from 22 days after planting, with manual application of $200 \mathrm{~kg} \mathrm{ha}^{-1}$, following the recommendations of 50 to $75 \mathrm{~kg} \mathrm{ha}^{-1}$ of $\mathrm{N}$, approximately, per month and the $\mathrm{N}: \mathrm{K}$ ratio of 1:1.5. After fertilizer application, the grass was irrigated and invasive plants were manually controlled whenever necessary. Along the experimental period, the temperature ranged from 22.5 to $31.8^{\circ} \mathrm{C}$, with total precipitation of $590 \mathrm{~mm}$.

The variables root length, photosynthesis rate, dry mass of roots, stolons, rhizomes, culms and leaves, and dry mass of grass clippings were analyzed at 105 days after planting, a phase in which the grass was already established and the soil was almost completely covered.

Root length was determined from the collection of four plugs, one per replicate, with size of $100 \mathrm{~cm}^{2}$ and depth of 20 $\mathrm{cm}$. The soil adhered to the roots was removed and length was measured with a tape measure.

Photosynthesis rate was measured using a gas exchange meter, IRGA (LICOR 6400XT, Licor, USA). Measurements were taken between 9:00 a.m. and 11:00 a.m., using artificial radiation light source of $1400 \mu \mathrm{mol} \mathrm{m} \mathrm{m}^{-2} \mathrm{~s}^{-1}$.

After measuring the roots, the plugs were separated into roots, stolons and rhizomes and into leaves and culms to determine dry mass.

The dry mass of grass clippings was determined with the aid of a lawn mower with a collector attached, in the observation plot (with $0.10 \mathrm{~m}$ border).

In the analysis of the Crop Susceptibility factor (CS), the dry mass of grass clippings was used as a reference variable, considering that the greater the crop growth, the larger the amount of clippings collected and, therefore, its yield.

The crop susceptibility factor is determined experimentally, based on the critical level of stress to which the crop was subjected during each stage of physiological development, as well as on the quantification of its yield response, and can be calculated by Eq. 3:

$$
\mathrm{CS}=\frac{\mathrm{Yo}-\mathrm{Yi}}{\mathrm{Yo}_{0}}
$$

where:

CS - crop susceptibility; 
Yo - crop yield without stress; and,

Yi - crop yield under stress conditions at stage $i$.

The crop susceptibility factor for each growth stage was determined according to the amount of dry mass of the clippings, both with no level of stress (control) and under the stress caused at the different stages of development.

The data were subjected to analysis of variance, considering $\mathrm{p} \leq 0.05$, followed by regression analysis.

\section{Results AND Discussion}

Root length varied from $9.25 \mathrm{~cm}$, under the highest stress by excess water $(450 \mathrm{~cm} \mathrm{~d})$, to $16.00 \mathrm{~cm}$, in the control treatment, where the water table was kept at the level of the drains (1.10 m) (Figure 2).

The increment in the stress caused by excess water near the surface resulted in a reduction in root length, also reducing the capacity of the plant to explore and take advantage of a greater amount of soil and nutrients. The lack of nutrients caused, for example, by water stress, hampers the development of the grasses, as of any other crop, preventing plants from maintaining their exuberance (Lima et al., 2015).

These results corroborate the statement of Romero \& Dukes (2016), who discusses the limitations related to frequent water application and drainage problems, which can reduce the concentration of air in the soil and create an unfavorable environment for root growth. Therefore, the accumulation of water, either due to difficulty in drainage or excessive irrigations, can hamper the development of the root system, resulting in a shorter length of the roots, and soil water content is an important factor in the alteration of dry mass and root volume. It is worth pointing out that the lawn that maintains low daily water use rate will enable the permanence of water in the soil, favoring the maintenance of quality for longer periods (Cathey et al., 2013; Koetz et al., 2017).

Jiang \& Wang (2006) consider the reduction in carbohydrate content, as a function of the increase in stress caused by excess

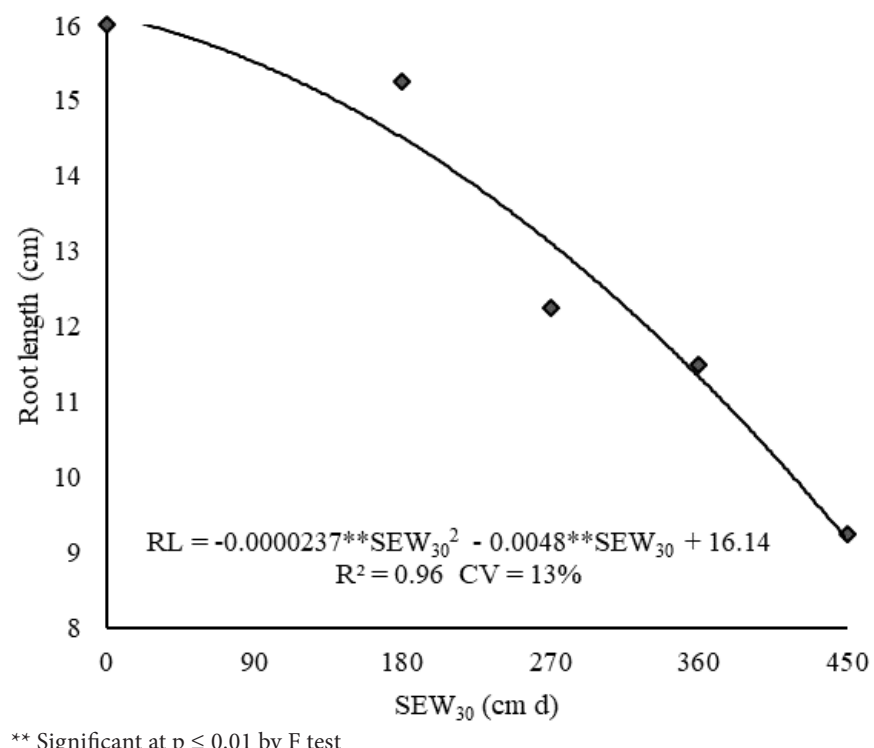

Figure 2. Root length of Bermuda grass as a function of the sum of water excess above $0.30 \mathrm{~m}$ depth $\left(\mathrm{SEW}_{30}\right)$ water, as one of the main factors for reducing the growth of grass roots.

Rapid extension of roots in the soil is essential for obtaining water and nutrients to favor the establishment of the lawn. Thus, it is necessary to provide adequate supply of water and nutrients, based on environmental and plant factors, and minimize the impacts of these factors, which is crucial for a successful establishment of the lawn (Sinclair et al., 2011; Curk et al., 2017).

Plants, under excess water conditions, reduce stomatal conductance due to the increase in stomatal resistance, which limits water absorption, causing internal water deficit. The net photosynthesis rate decreases under oxygen deficiency, and the reductions in transpiration and photosynthesis are attributed to stomatal closure (Folzer et al., 2006; Parent et al., 2008; Ashraf et al., 2011).

The photosynthesis rate as a function of $\mathrm{SEW}_{30}$ levels decreased with the increment in the level of stress by excess water in the soil, and a second-degree polynomial statistical model fitted to the data, as shown in Figure 3. The photosynthesis rate decreased by $64 \%$ between the stress-free treatment and the treatment corresponding to the water table level of $0.10 \mathrm{~m}$ from the soil surface.

Mattos et al. (2005) observed that excess water reduces photosynthesis rate and growth, resulting in a decrease in biomass production; in addition, it should be emphasized that there is a higher incidence of diseases and difficulty in controlling invasive plants (Silveira et al., 2014).

Another factor that interferes with the photosynthesis rate is chlorophyll. The chlorophyll molecule has the unique ability to convert solar energy into chemical energy (photosynthesis). In this process, light energy is used by plants in the synthesis of carbohydrates and, according to Jiang \& Wang (2006), stress by water excess causes reduction in the synthesis of carbohydrates and chlorophyll, causing the plant to decrease its development, losing its original color (Godoy et al., 2016). In the study, plants subjected to higher level of stress by water excess showed loss of color and were more yellowish, which may be related to the situation described above.

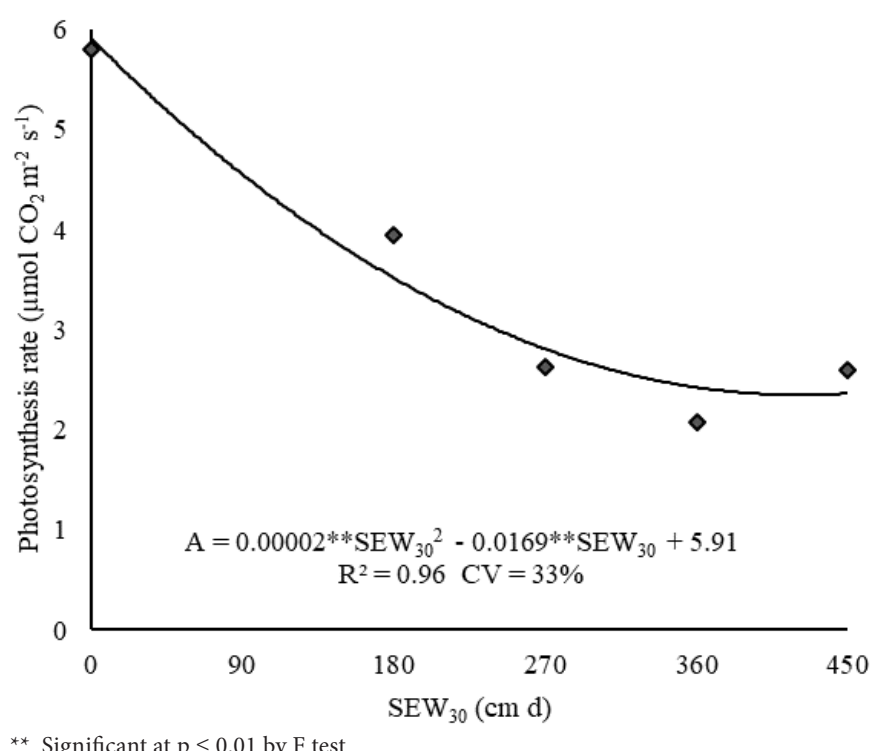

Figure 3. Photosynthesis rate of Bermuda grass as a function of excess water above $0.30 \mathrm{~m}$ depth $\left(\mathrm{SEW}_{30}\right)$ 
The results for dry masses of roots, rhizomes and stolons did not show significant differences according to the treatments evaluated (Figure 4A). For the dry mass of culms and leaves, the treatment 1 , with the water table kept at the drain level, differed statistically from the treatments $4,5,3$ and 2, with reductions of 65, 67, 70 and 75\%, respectively (Figure 4B).

Leaves are organs that have developed the ability to capture light and exchange gases with the atmosphere to perform photosynthesis and respiration. Photosynthesis occurs in chloroplasts, which in grasses is found mainly in culms and leaves. Plant growth, in general, is dependent on cell division and expansion, and the expansion is conditioned by turgor pressure, a process that is affected by the low availability of water in the soil or by excessive transpiration (Santos et al., 2014).

The dry mass of roots, rhizomes and stolons and the dry mass of culms and leaves decreased under the condition of elevated water table, following the pattern observed in the photosynthesis rate.

The values of dry mass of grass clippings in the control treatment and in stress treatments at three different stages

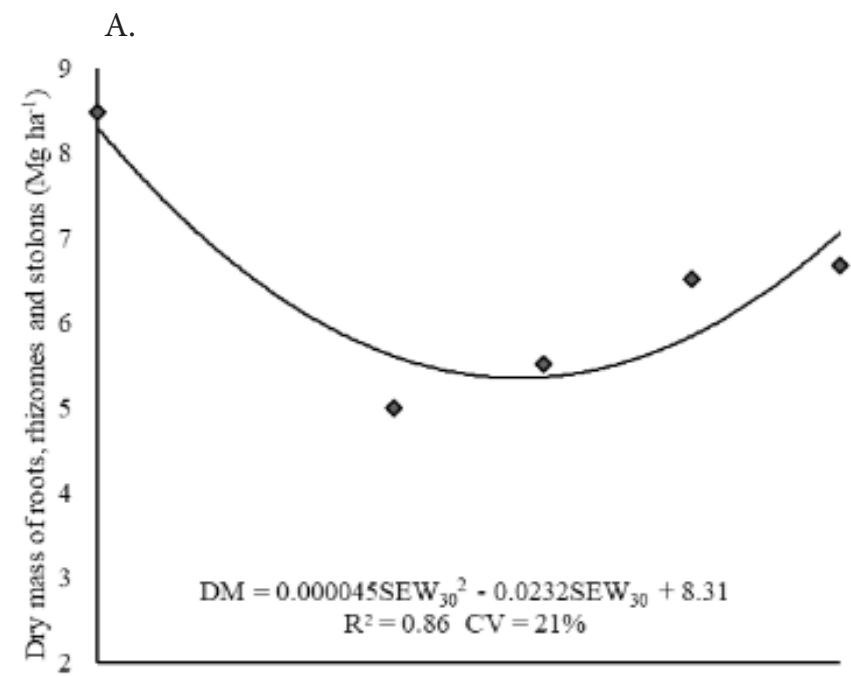

B.

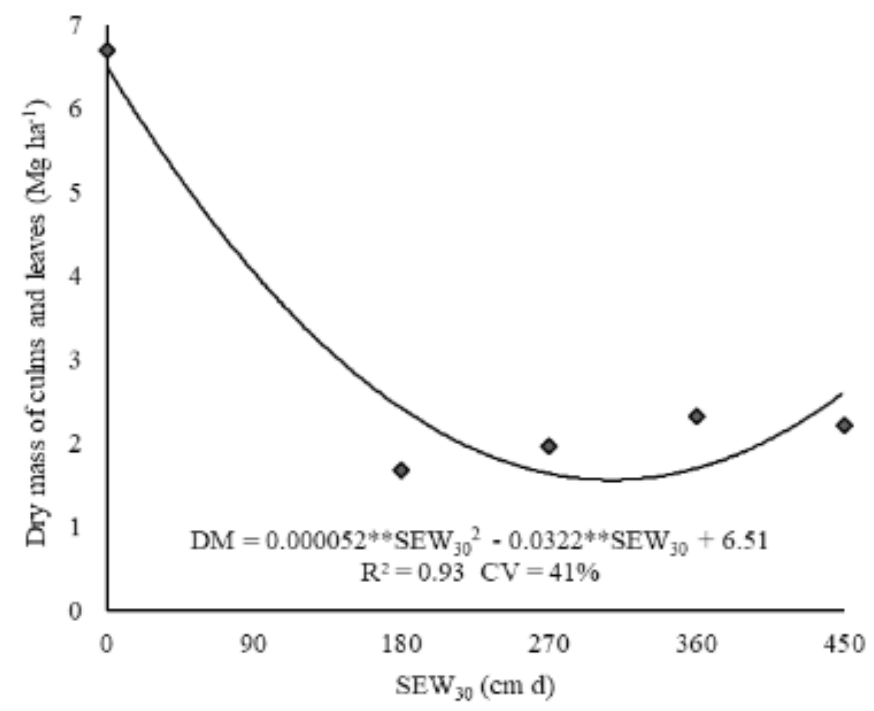

** - Significant at $\mathrm{p} \leq 0.01$ by F test

Figure 4. Dry mass of roots, rhizomes and stolons (A) and dry mass of culms and leaves (B) of Bermuda grass as a function of excess water above $0.30 \mathrm{~m}$ depth $\left(\mathrm{SEW}_{30}\right)$ of development were: Control, 4,704.36 kg ha-1; 1st Stage, 3,262.23 $\mathrm{kg} \mathrm{ha}^{-1}$; 2nd Stage, 3,887.28 $\mathrm{kg} \mathrm{ha}^{-1}$; and 3rd Stage, $3,805.88 \mathrm{~kg} \mathrm{ha}^{-1}$.

The obtained values of crop susceptibility factor were: $\mathrm{CS}_{1}$ $=0.306 ; \mathrm{CS}_{2}=0.174 ; \mathrm{CS}_{3}=0.191$, respectively, in the first, second and third stages, demonstrating that the crop was more sensitive in the first stage.

The weighted average of the CS index, corresponding to 0.22 , and the values of $\mathrm{SEW}_{30}$ for each of the treatments were used to calculate the values of Stress-Day Index (SDI), which corresponded to: $0,37.6,59.4,79.2$ and $99.0 \mathrm{~cm} \mathrm{~d}$, for the $\mathrm{SEW}_{30}$ values of $0,180,270,360$ and $450 \mathrm{~cm}$, respectively.

The functional relationship between the stress-day index (SDI) and the sum of excess water (SEW) showed positive linear behavior between the variables (Figure 5), suggesting an increase of $0.22 \mathrm{~cm} \mathrm{~d}$ in the stress-day index for every 1.0 $\mathrm{cm} \mathrm{d}$ increment in the sum of excess water.

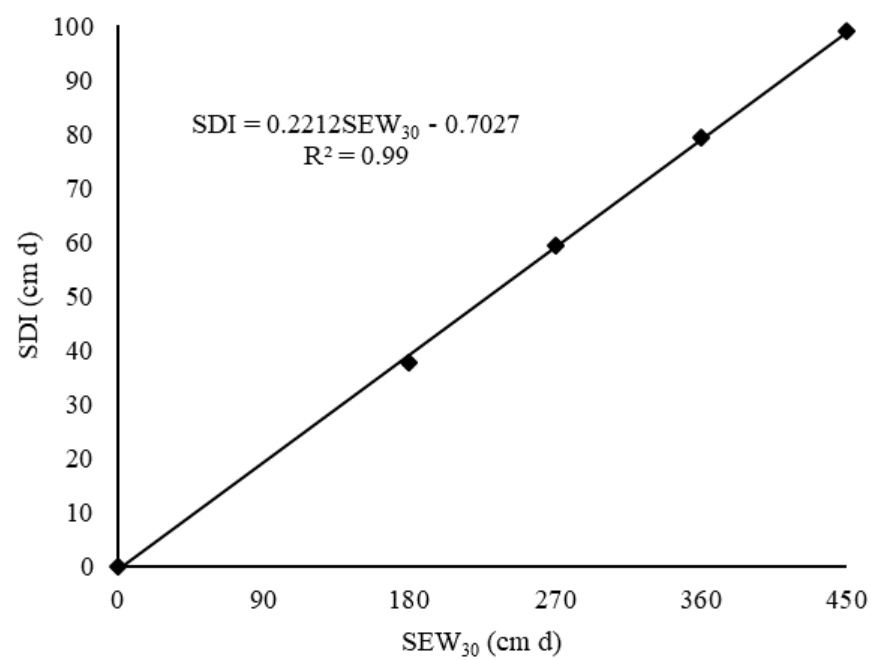

Figure 5. Stress-day index (SDI) in Bermuda grass as a function of excess water above $0.30 \mathrm{~m}$ depth $\left(\mathrm{SEW}_{30}\right)$

\section{Conclusions}

1. Photosynthesis rate in the treatment with higher stress level decreased by approximately $2 / 3$ when compared to the condition of no water table.

2. Stress caused by excess water near the soil surface led to reduction in root length, dry mass of culms and leaves, and photosynthesis rate.

3. Bermuda grass is more sensitive to excess water in the soil at the initial vegetative stage, which occurs until 42 days after planting.

\section{Literature Cited}

Ashraf, M. A.; Ahmad, M. S. A.; Ashraf, M.; Al-Qurainy, F.; Ashraf, M. Y. Alleviation of waterlogging stress in upland cotton (Gossypium hirsutum L.) by exogenous application of potassium in soil and as a foliar spray. Crop Pasture Science, v.62, p.25-38, 2011. https:// doi.org/10.1071/CP09225

Bouwer, H. Developing drainage design criteria. In: Schilfgaarde, J. van. (ed.) Drainage for agriculture. Madison: American Society of Agronomy, 1974. Chap.5, p.67-79. https://doi.org/10.2134/ agronmonogr17.c5 
Cathey, S. E.; Kruse, J. K.; Sinclair, T. R.; Dukes, M. D. Transpiration and visual appearance of warm season turfgrasses during soil drying. Environmental and Experimental Botany, v.89, p.36-43, 2013. https://doi.org/10.1016/j.envexpbot.2012.12.004

Costa, R. N. T.; Vasconcelos, J. P.; Silva, L. A.; Ness, R. L. L. Interferência do excesso de água no solo e componentes de produção em beterraba. Horticultura Brasileira, v.26, p.74-77, 2008. https://doi.org/10.1590/S0102-05362008000100014

Curk, M.; Vidrih, M.; Laznik, Ž.; Trdan, S. Turfgrass maintenance and management in soccer fields in Slovenia. Urban Forestry \& Urban Greening, v.26, p.191-197, 2017. https://doi.org/10.1016/j. ufug.2016.08.003

Evangelista, A. W. P.; Ferreira, P. A.; Pruski, F. F.; Sediyama, G. C. Desenvolvimento e aplicação de metodologia para dimensionamento de sistemas de drenagem agrícola. Revista Brasileira de Engenharia Agrícola e Ambiental, v.9, n.4, p.441449, 2005. https://doi.org/10.1590/S1415-43662005000400001

Folzer, H.; Dat, J.; Capelli, N.; Rieffel, D.; Badot, P. M. Response of sessile oak seedlings (Quercus petraea) to flooding: an integrated study. Tree Physiology, v.26, p.759-766, 2006. https://doi. org/10.1093/treephys/26.6.759

Godoy, L. J. G. de; Barbosa, M. R. V. X.; Ferraz, M. V.; Saes, L. A.; Ferraz, M. V. Dose and mode of application of the water-absorbent copolymer on growth of bermudagrass. Irriga, v.1, p.168-178, 2016. https://doi.org/10.15809/irriga.2016v1n01p168-178

Godoy, L. J. G. de; Villas Bôas, R. L.; Backes, C. Produção de tapetes de grama Santo Agostinho submetida a doses de nitrogênio. Semina: Ciências Agrárias, v.33, p.1703-1716, 2012. https://doi. org/10.5433/1679-0359.2012v33n5p1703

Jiang, Y.; Wang, K. Growth, physiological, and anatomical responses of creeping bentgrass cultivars to different depths of waterlogging. Crop Science, v.46, p.2420-2426, 2006. https://doi.org/10.2135/ cropsci2005.11.0402

Koetz, M.; Bär, C. S. L. L.; Pacheco, A. B.; Castro, W. J. R. de; Crisostomo, W. L.; Silva, E. M. B. da. Produção e eficiência no uso da água do capim paiaguás sob tensões de água no solo. Revista Brasileira de Agricultura Irrigada, v.11, p.1223-1232, 2017. https:// doi.org/10.7127/rbai.v11n100571

Kuhn, M. Projeto gramados esportivos Copa do Mundo FIFA 2014. In: Mateus, C. M. D.; Villas Bôas, R. L.; Andrade, T. F.; Oliveira, M. R.; Backes, C.; Santos, A. J. M.; Godoy, L. J. G. de. (eds.) Tópicos atuais em gramados IV. Botucatu: FEPAF/UNESP/FCA, 2015. Cap.2, p.23-34.

Lemes, E. S.; Oliveira, S. de; Almeida, A. da S.; Meneghello, G. E.; Gewehr, E.; Tunes, L. M. de. Testes de vigor para avaliação da qualidade de sementes de grama-bermuda. Revista de la Facultad de Agronomía, v.114, p.185-192, 2015.

Lima, C. P. de; Backes, C.; Santos, A. J. M.; Fernandes, D. M.; Villas Bôas, R. L.; Oliveira, M. R. de. Quantidade de nutrientes extraídos pela grama bermuda em função de doses de nitrogênio. Bioscience Journal, v.31, p.1432-1440, 2015. https://doi.org/10.14393/BJv31n5a2015-21967
Maciel, C. D. G.; Poletine, J. P.; Raimondi, M. A.; Rodrigues, M.; Ribeiro, R. B.; Costa, R. S.; Maio, R. M. D. Desenvolvimento de gramados submetidos à aplicação de retardadores de crescimento em diferentes condições de luminosidade. Planta Daninha, v.29, p.383-395, 2011. https://doi.org/10.1590/S010083582011000200016

Mattos, J. L. S.; Gomide, J. A.; Huaman, C. A. M. Crescimento de espécies do gênero Brachiaria sob alagamento em casa de vegetação. Revista Brasileira de Ciências do Solo, v.34, p.765-773, 2005. https://doi.org/10.1590/S1516-35982005000300007

Parent, C.; Berger, A.; Folzer, H.; Dat, J.; Crevecoeur, M.; Badot, P. M.; Capelli, N. A novel nonsymbiotic hemoglobin from oak: Cellular and tissue specificity of gene expression. New Phytologist, v.177, p.142-154, 2008. https://doi.org/10.1111/ j.1469-8137.2007.02250.x

Romero, C. C.; Dukes, M. D. Review of turfgrass evapotranspiration and crop coefficients. American Society of Agricultural and Biological Engineers, v.59, p.207-223, 2016. https://doi. org/10.13031/trans.59.11180

Sampoux, J. P.; Baudouin, P.; Bayle, B.; Beguier, V.; Bourdon, P.; Chosson, J. F.; Bruijn, K. de; Deneufbourg, F.; Galbrun, C.; Ghesquiere, M.; Noe, D.; Tharel, B.; Viguie, A. Breeding perennial ryegrass (Lolium perenne L.) for turf usage: An assessment of genetic improvements in cultivars released in Europe, 19742004. Grass Forage Science, v.68, p.33-48, 2012. https://doi. org/10.1111/j.1365-2494.2012.00896.x

Santos, J. C. C. dos; Silva, C. H. da; Santos, C. S. dos; Silva, C. de S.; Melo, E. B.; Barros, A. C. Análise de crescimento e evapotranspiração da cultura do rabanete submetido a diferentes lâminas de água. Revista Verde de Agroecologia e Desenvolvimento Sustentável, v.9, p.151-156, 2014.

Silva, C. B.; Pivetta, K. F. L.; Oliveira, C. A. V. M.; Rodrigues, M. A.; Vieira, R. D. Teste de envelhecimento acelerado para avaliação do potencial fisiológico de sementes de grama-bermuda. Revista Brasileira de Sementes, v.32, p.102-107, 2010. https://doi. org/10.1590/S0101-31222010000200012

Silveira, H. R. de O.; Santos, M. de O.; Alves, J. D.; Souza, K. R. D. de; Andrade, C. A.; Alves, R. G. M. Growth effects of water excess on coffee seedlings (Coffea arabica L.). Acta Scientiarum. Agronomy, v.36, p.211-218, 2014. https://doi.org/10.4025/actasciagron. v36i2.17557

Sinclair, T. R.; Schreffler, A.; Wherley, B.; Dukes, M. D. Irrigation frequency and amount effect on root extension during sod establishment of warm-season grasses. Hortscience, v.46, p.12021205, 2011. https://doi.org/10.21273/HORTSCI.46.8.1202

USGA - United States Golf Association. Recommendations for a method of putting green construction. USGA: Green Section, 2004. 11p. Available at: <https://www.usga.org/content/dam/usga/ images/course-care/2004\%20USGA\%20Recommendations\%20 For\%20a\%20Method\%20of\%20Putting\%20Green\%20Cons.pdf>. Accessed on: Mar. 2019. 